Research Paper

\title{
Thrombus Aspirated from Patients with ST-Elevation Myocardial Infarction: Association between 3-Nitrotyrosine and Inflammatory Markers - Insights from ARTERIA Study
}

\author{
Alberto Dominguez-Rodriguez ${ }^{1,2}{ }^{\bowtie}$, Pedro Abreu-Gonzalez ${ }^{3}$, Luciano Consuegra-Sanchez ${ }^{4}$, Pablo \\ Avanzas ${ }^{5}$, Alejandro Sanchez-Grande ${ }^{1}$, Pablo Conesa-Zamora ${ }^{6}$ \\ 1. Hospital Universitario de Canarias. Servicio de Cardiología. Santa Cruz de Tenerife. Spain. \\ 2. Facultad de Ciencias de la Salud. Universidad Europea de Canarias. La Orotava. Santa Cruz de Tenerife. Spain. \\ 3. Departamento de Ciencias Médicas Básicas (Unidad de Fisiología), Universidad de La Laguna. Santa Cruz de Tenerife. Spain. \\ 4. Hospital Universitario de Santa Lucía de Cartagena, Servicio de Cardiología. Murcia. Spain. \\ 5. Hospital Universitario Central de Asturias. Área del Corazón. Oviedo. Spain. \\ 6. Hospital Universitario de Santa Lucía de Cartagena, Servicio de Anatomía Patológica. Murcia. Spain. \\ $\triangle$ Corresponding author: Dr Alberto Dominguez-Rodriguez, Hospital Universitario de Canarias, Department of Cardiology. Ofra s/n La Cuesta E-38320. \\ Tenerife. Spain. Telephone: + 34922679040 Fax: + 34922 678460.e-mail: adrvdg@hotmail.com.
}

(C) Ivyspring International Publisher. Reproduction is permitted for personal, noncommercial use, provided that the article is in whole, unmodified, and properly cited. See http://ivyspring.com/terms for terms and conditions.

Received: 2016.03.06; Accepted: 2016.05.04; Published: 2016.06.18

\begin{abstract}
Recent studies have demonstrated that inflammatory cells are a component that plays a role in thrombus formation in ST-elevation myocardial infarction (STEMI). 3-nitrotyrosine (3-NO $-\mathrm{Tyr}$ ), a specific marker for protein modification by nitric oxide-derived oxidants, is increased in human atherosclerotic lesions. The purpose of this study was to determine the possible association of inflammatory markers of coronary thrombi with nitroxidative stress. Intracoronary thrombus $(n=51)$ and blood from the systemic circulation were obtained by thromboaspiration in 138 consecutive STEMI patients presenting for primary percutaneous coronary intervention $(\mathrm{PCI})$. Each blood and intracoronary thrombus were measured simultaneously the following biomarkers: C-reactive protein (CRP), 3-NO $-\mathrm{Nyr}$, soluble CD 40 ligand (sCD40L), vascular cellular adhesion molecule-1 (VCAM-1) and haemoglobin content (only in coronary thrombus).

Time delay in minutes from symptom onset to $\mathrm{PCl}$ was $244 \pm 324$. Serum CRP was positively correlated to CRP content in the thrombus $(r=0.395 ; p=0.02)$ and serum $s C D 40 L$ was negatively correlated to sCD40L in the thrombus $(r=-0.394 ; p=0.02)$. Patients were divided into tertiles according to thrombi $3-\mathrm{NO}_{2}-\mathrm{Tyr}$ concentration: $1^{\text {st }}$ tertile $(<0.146 \mathrm{ng} / \mathrm{mg}), \quad 2^{\text {nd }}$ tertile $(0.146-0.485 \mathrm{ng} / \mathrm{mg})$ and $3^{\text {rd }}$ tertile $(>0.485 \mathrm{ng} / \mathrm{mg})$. Thus, thrombus in the highest tertile had significantly higher levels of CRP $(p=0.002)$ VCAM-1 $(p=0.003)$ and haemoglobin $(p=0.002)$. In conclusion, the present study demonstrated that coronary thrombi with higher levels of 3-NO $\mathrm{NO}_{2}-\mathrm{Ty}$ content often contain more inflammatory markers which could have a direct impact on the efficacy of drugs or devices used for coronary reperfusion.
\end{abstract}

Key words: coronary thrombosis; inflammation; myocardial infarction; oxidative stress; percutaneous coronary intervention.

\section{Introduction}

Acute coronary thrombosis resulting in total occlusion of a coronary artery leads to ST-segment elevation myocardial infarction (STEMI) [1]. The mechanisms of thrombus formation on disrupted and eroded atherosclerotic plaques have been the subject of substantial investigation [2-5]. Thromboaspiration 
in primary percutaneous coronary intervention (PCI) for STEMI provides a unique opportunity in studying thrombus composition in vivo [6,7]. Thrombosis is a complex mechanical phenomenon that involves the interaction of cellular components of platelets, red blood cells, fibrin and inflammatory cells that make up coronary thrombus [8-11]. Formation of nitric oxide-derived oxidants may serve as a mechanism linking inflammation to development of atherosclerosis [12]. 3-Nitrotyrosine $\left(3-\mathrm{NO}_{2}-\mathrm{Tyr}\right)$, a specific marker for protein modification by nitric oxide-derived oxidants, is enriched in human atherosclerotic lesions [13]. However, the relationship of the 3- $\mathrm{NO}_{2}-\mathrm{Tyr}$ in the thrombus with inflammatory markers in STEMI patients has never been investigated. This study aims to ascertain the association between inflammatory markers of coronary thrombi with 3-NO2-Tyr in STEMI-patients treated with thrombus aspiration.

\section{Methods}

\section{Patients}

The design of this study has been published previously [14]. 138 consecutive STEMI patients who underwent thrombus aspiration during primary PCI are included in this study. Briefly, the inclusion criteria were: patients of both sexes, with no age limit, with a diagnosis of STEMI within 12 hours from symptom onset. STEMI was defined as the presence of compatible symptoms, persistent elevation (> $20 \mathrm{~min}$ ) of ST segment $\geq 1 \mathrm{~mm}$ in at least two contiguous leads, or left bundle-branch block presumably of new onset and elevation of cardiac troponin I [15]. Patients who had $\geq 50 \%$ left main coronary artery stenosis, thrombolytic therapy before $\mathrm{PCI}$, renal dysfunction (serum creatinine levels $\geq 2.0 \mathrm{mg} / \mathrm{dL}$ ), concomitant inflammatory diseases, or malignant tumours were excluded from this study. If no material was obtained or if the aspirated material could not be analyzed from patients, they were deemed to be ineligible. A total of 51 patients were finally enrolled in the study (Figure 1). The research protocol was approved by the ethics committee. All patients gave written consent for inclusion. This study was registered at ClinicalTrials.gov no. NCT01757886.

PCI was carried out according to guidelines. The 6F Export catheter (Medtronic) or a Pronto catheter (Vascular Solution) was used to perform the manual aspiration. The aspiration was incised $2 \mathrm{~cm}$ before the thrombus lesion. The thrombectomy catheter was then moved forward very slowly with continuous aspiration and the lesion was crossed. It is recommended to use a second or third syringe. The aspiration of blood from the guiding catheter was made possible through continuous aspiration while the thrombectomy catheter was removed. It is also recommended to make additional passages until no signs of thrombus are observed on an angiogram. Loading dose of clopidogrel, prasugrel or ticagrelor was administered. Aspirin was administered as a 300 $\mathrm{mg}$ loading dose followed by $100 \mathrm{mg} /$ day. Full doses of i.v. heparin was administered to the patients before either PCI $(1 \mathrm{mg} / \mathrm{kg})$ or $0.7 \mathrm{mg} / \mathrm{kg}$ for patients who received abciximab. Dosages of GPIIb/IIIa were bolus of $0.25 \mathrm{mg} / \mathrm{kg}$ i.v. and $0.125 \mathrm{mg} / \mathrm{kg} / \mathrm{min}$ infusion (maximum $10 \mathrm{mg} / \mathrm{min}$ ) for $12 \mathrm{~h}$.

Clinical, angiographic and laboratory data were prospectively collected in an electronic database.

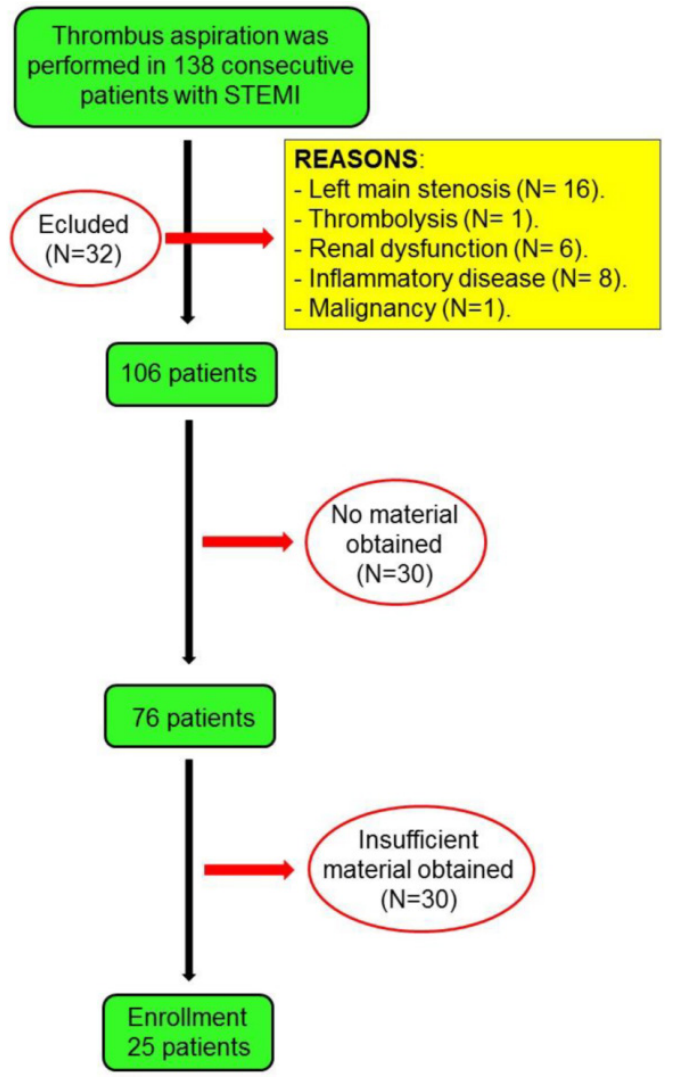

Figure 1. Flow chart of the study.

\section{Sample collection}

Each thrombus obtained was washed in situ twice with cold saline solution and dried on absorbent paper. The dry thrombi were stored by freezing at$80^{\circ} \mathrm{C}$ until they were processed. For their analysis, the thrombi were homogenized in a glass mortar with 1 $\mathrm{mL}$ cold saline solution and then were disaggregated using ultrasound homogenizer, 10 seconds at $100 \mathrm{w}$ in cold conditions. The appropriate analytical measurements were performed in this homogenized material. Peripheral bloods were drawn from the 
patients at the same time as the thrombi were extracted. The serum was obtained after coagulation and centrifugation of the blood and were fractionated in aliquots and stored at $-70^{\circ} \mathrm{C}$ until their analysis. Personnel, blinded to patient's baseline characteristics and clinical outcomes, carried out all measurements.

Analytical variables analysed both in thrombus and serum concentrations were measured using a commercially available enzyme-linked immunoabsorbent assay kits according to the manufacture's specifications. The coefficients of variation and limit of detection are expressed in Table 1.

Table 1. Enzyme-linked immunoabsorbent assay kits according to the manufacture's specifications.

\begin{tabular}{|c|c|c|c|c|}
\hline Biomarkers & $\begin{array}{l}\text { CV (\%) } \\
\text { (intra- } \\
\text { assay) }\end{array}$ & $\begin{array}{l}\text { CV (\%) } \\
\text { (inter- } \\
\text { assay) }\end{array}$ & LOD & Manufacturer Company \\
\hline CRP & 3.28 & 4.4 & $0.1 \mathrm{mg} / \mathrm{L}$ & $\begin{array}{l}\text { DRG Instrument } \mathrm{GmbH} \text {, } \\
\text { Germany }\end{array}$ \\
\hline $3-\mathrm{NO}_{2}-\mathrm{Tyr}$ & 6.9 & 13 & $2.02 \mathrm{ng} / \mathrm{ml}$ & Abcam, UK \\
\hline sCD40L & 4 & 6.8 & $0.06 \mathrm{ng} / \mathrm{ml}$ & $\begin{array}{l}\text { Bender MedSystems } \\
\text { GmbH, Germany }\end{array}$ \\
\hline VCAM-1 & 3.1 & 5.2 & $0.6 \mathrm{ng} / \mathrm{ml}$ & $\begin{array}{l}\text { IBL International GmbH, } \\
\text { Germany }\end{array}$ \\
\hline Haemoglobin & 2.12 & 3.88 & $0.022 \mathrm{mg} / \mathrm{ml}$ & Sigma-Aldrich Co, USA \\
\hline
\end{tabular}

$\mathrm{CV}=$ coefficients of variation. $\mathrm{LOD}=$ limit of detection. $\mathrm{hsCRP}=$ high sensitivity C-reactive protein. 3- $\mathrm{NO}_{2}-\mathrm{Tyr}=3$-nitrotyrosine. $\mathrm{sCD} 40 \mathrm{~L}=$ soluble $\mathrm{CD} 40$ ligand.

VCAM-1 = vascular cellular adhesion molecule-1.

\section{Statistical analysis}

Univariate analyses were performed, and the frequencies and percentages were recorded for each categorical variable, along with the mean \pm standard deviation (SD) of the quantitative variables. Those variables that did not meet normality were presented as median and interquartile range (IQR). The Kolmogorov-Smirnov test was used to analyze the normal distribution of variables. For the purpose of the analysis and clinical interpretation, patients were divided into tertiles according to thrombi 3- $\mathrm{NO}_{2}-\mathrm{Tyr}$ concentration. Groups were compared using ANOVA test with Dunnett's correction for multiple comparisons. The association between quantitative variables was studied using the Spearman Correlation test. Statistical significance was set at $p<0.05$. Statistical analysis was performed using SPSS, version 20.0, software (IBM, Copr.; Armonk, New York, USA).

\section{Results}

The baseline characteristics of the patients are shown in Table 2. Forty-one (80.3\%) were men and mean age was $57 \pm 12$ years. Prevalence of traditional coronary artery disease risk factors, such as dyslipidemia, smoking, hypertension and diabetes mellitus was $52.9 \%, 51.0 \%, 45.1 \%$ and $21.6 \%$ respectively. Mean body mass index was $28.9 \pm 4.2$ $\mathrm{kg} / \mathrm{m}^{2}$ and $15 \%$ patients had previous cardiovascular disease. Study participants showed a leukocytes and platelets count of $12.3 \pm 5.0$ and $248 \pm 82 \mathrm{~mm}^{3} \times 1000$, respectively. Mean haematocrit was $43 \pm 6 \%$. Mean ischemic time (from symptom onset to PCI) was $244 \pm$ $324 \mathrm{~min}$. The infarct-related artery more prevalent was left anterior descending coronary $(45.1 \%)$. Our population included $88.2 \%$ of patients with TIMI 0 flow on admission. The incidence of angiographic no-reflow was $2 \%$. Mean left ventricular ejection fraction was $56 \pm 11 \%$. Aggressive treatment of high doses of clopidogrel, prasugrel or ticagrelor and abciximab in addition to aspirin and low molecular weight or unfractionated heparin were given to a high number of patients.

Table 2. Baseline characteristics $(n=51)$.

\begin{tabular}{|c|c|}
\hline \multicolumn{2}{|l|}{ Demographics and risk factors } \\
\hline Age (years) & $57 \pm 12$ \\
\hline Women & $19.6 \%$ \\
\hline Dyslipidemia & $52.9 \%$ \\
\hline Active smoker & $51.0 \%$ \\
\hline Hypertension & $45.1 \%$ \\
\hline Diabetes mellitus & $21.6 \%$ \\
\hline BMI $\left(\mathrm{kg} / \mathrm{m}^{2}\right)$ & $28.9 \pm 4.2$ \\
\hline \multicolumn{2}{|l|}{ Past medical history of } \\
\hline Previous IHD & $15.7 \%$ \\
\hline Previous PCI & $14.7 \%$ \\
\hline Peripheral arteriopathy & $11.8 \%$ \\
\hline \multicolumn{2}{|l|}{ Biomarkers on admission } \\
\hline Haematocrit, $\%$ & $43 \pm 6$ \\
\hline Leukocytes (/mm3, x1000) & $12.3 \pm 5.0$ \\
\hline Platelets $(/ \mathrm{mm} 3, x 1000)$ & $248 \pm 82$ \\
\hline HDL-Cholesterol (mg/ml) & $39 \pm 11$ \\
\hline LDL-Cholesterol (mg/ml) & $98 \pm 35$ \\
\hline Tryglicerides, $(\mathrm{mg} / \mathrm{ml})$ & $159 \pm 72$ \\
\hline Glomerular filtration rate, $\mathrm{mL} / \mathrm{min}$ & $127 \pm 37$ \\
\hline \multicolumn{2}{|l|}{ Clinical presentation on admission } \\
\hline Killip class $>2$ & $9.8 \%$ \\
\hline Mean ischemic time (from symptom onset to PCI) & $244 \pm 324$ \\
\hline \multicolumn{2}{|l|}{ Angiographic results } \\
\hline Infarct-related artery: LAD & $45.1 \%$ \\
\hline Proximal segment involved & $47.1 \%$ \\
\hline Initial TIMI 0 flow & $88.2 \%$ \\
\hline$>1$ vessel diseased $(>70 \%)$ & $17.7 \%$ \\
\hline Slow-flow/non-reflow & $2.0 \%$ \\
\hline Stent deployment & $90.2 \%$ \\
\hline$\geq 2$ stents deployed & $17.7 \%$ \\
\hline Baseline vessel diameter, $\mathrm{mm}$ & $3.0 \pm 0.6$ \\
\hline Stenosis before aspiration, \% & $97.3 \pm 9.2$ \\
\hline Residual stenosis after PCI, \% & $7.9 \pm 13.8$ \\
\hline $\mathrm{LVEF}, \%$ & $56 \pm 11$ \\
\hline \multicolumn{2}{|l|}{ Antithrombotic treatment } \\
\hline ASA & $100 \%$ \\
\hline Clopidogrel & $68 \%$ \\
\hline Prasugrel & $12 \%$ \\
\hline Ticagrelor & $20 \%$ \\
\hline Abciximab & $74.1 \%$ \\
\hline Enoxaparin or unfractionated heparin & $100 \%$ \\
\hline
\end{tabular}

Values are mean \pm SD or percentages.

$\mathrm{BMI}=$ body mass index; $\mathrm{IHD}=$ ischemic heart disease; $\mathrm{PCI}=$ percutaneous coronary intervention; $\mathrm{LAD}=$ left anterior descending coronary artery; TIMI = Thrombolysis In Myocardial Infarction; LVEF = left ventricular ejection fraction; ASA $=$ acetylsalicylic acid. 


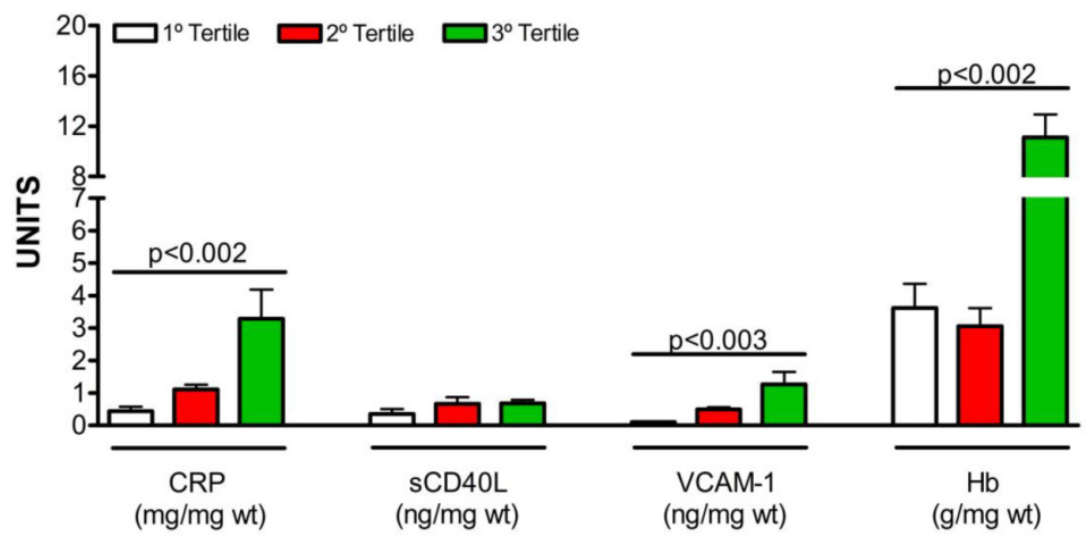

Figure 2. . Relationship between nitroxidative stress and inflammatory markers in the intracoronary thrombus. 3- $\mathrm{NO}_{2}-\mathrm{Tyr}=3-\mathrm{nitrotyrosine} ; \mathrm{CRP}$ $=$ high sensitivity $C$-reactive protein; $\mathrm{SCD} 40 \mathrm{~L}=$ soluble $C D 40$ ligand; $\mathrm{VCAM}-1=$ vascular cellular adhesion molecule- 1 . wt $=$ wet tissue.

51 thrombi was collected and analysed. A median hemoglobin of $3.52 \mathrm{~g} / \mathrm{mg}$ (IQR 1.88-6.43) was found in the thrombi. Table 3 shows the peripheral measure of sCD40L, the platelet activation marker. It had negative correlations with the platelet content in the thrombus $(r=-0.394, p=0.028)$. However, the peripheral measure CRP had positive correlations with CRP content in the thrombus $(\mathrm{r}=0.395, \mathrm{p}=$ 0.028). Although 3-NO2-Tyr and VCAM-1 in blood was simultaneously measured, there was no correlation with the thrombus content.

As shown in Figure 2, there were differences between the tertiles of $3-\mathrm{NO}_{2}$-Tyr with regard to associations of inflammatory markers in the intracoronary thrombus. Thrombus in the highest tertile of 3- $\mathrm{NO}_{2}$-Tyr had significantly higher content of CRP $\quad(p=0.002)$, VCAM-1 $\quad(p=0.003)$ and haemoglobin $(\mathrm{p}=0.002)$.

Table 3. Biomarkers and thrombus composition.

\begin{tabular}{|c|c|c|c|c|}
\hline & Serum & Thrombus & $\begin{array}{l}\text { Spearman } \\
\text { rho }\end{array}$ & $\begin{array}{l}\mathrm{P} \\
\text { value }\end{array}$ \\
\hline 3-NO2-Tyr, ng/ml(mg) & $20.2(11.7-38.5)$ & $0.28(0.11-0.68)$ & -0.167 & 0.369 \\
\hline CRP, mg/L(mg) & $2.56(1.69-4.73)$ & $0.76(0.27-1.77)$ & 0.395 & 0.028 \\
\hline $\mathrm{sCD} 40 \mathrm{~L}, \mathrm{ng} / \mathrm{ml}(\mathrm{mg})$ & $3.32(1.44-6.73)$ & $0.34(0.08-0.78)$ & -0.394 & 0.028 \\
\hline VCAM-1, ng/ml(mg) & $400(297-580)$ & $0.28(0.09-0.71)$ & 0.066 & 0.724 \\
\hline
\end{tabular}

\section{Discussion}

The recommended technique of thrombus aspiration facilitates thrombus removal from the offending coronary artery in myocardial infarction. It has also made it easier to investigate the in vivo composition of human coronary thrombi [16]. To the best of our knowledge, this is the first study to demonstrate the relationship between nitroxidative stress and inflammatory markers in the intracoronary thrombus.

Elevated plasma levels of CRP are independently associated with increased risk of atherothrombosis [17]. We found in our study that CRP in blood was positively correlated with CRP content within intracoronary thrombus. Takano et al [18] utilized angioscopy to evaluate by direct visualization 48 thrombi in 50 ruptured coronary plaques and the serum CRP level were measured. The mean angioscopic follow-up period was $13 \pm 9$ months. Superimposed thrombi still remained at follow-up in 35 lesions, and the predominant thrombus color changed from red (56\%) at baseline to pinkish-white $(83 \%)$ at follow-up. The serum CRP level in patients with healed plaques $(n=10)$ was lower than in those without healed plaques $(\mathrm{n}=19)$, $(0.07 \pm 0.03 \mathrm{mg} / \mathrm{dl}$ vs. $0.15 \pm 0.11 \mathrm{mg} / \mathrm{dl}$, respectively; $p=0.007)$. The authors concluded that the serum CRP level might reflect the disease activity of ruptured plaques. Moreover, recently, Matsuda et al [19] have demonstrated that elevated plasma human CRP levels promote thrombus formation on injured smooth muscle cell-rich neointima by enhancing tissue factor expression.

A platelet activation marker, sCD40L, an important pro-inflammatory mediator, directly participates in thrombus formation during the acute phase of acute myocardial infarction [20,21]. In platelets, sCD40L is rapidly translocated to the platelet surface after stimulation and is upregulated in fresh thrombus [21]. sCD40L levels in serum inversely correlates with sCD40L content thrombi, as shown by our results. The sCD40L is a biomarker with potential clinical implications, since the observed changes in serum in STEMI-patients might be influenced by antiplatelet agents, such as abciximab $[22,23,24]$

The artery wall is an important site of oxidative protein and it is related with pathologies such as atheromatosis [25]. Our study also suggests that those 
thrombus with higher 3- $\mathrm{NO}_{2}-\mathrm{Tyr}$ content often contain more inflammatory markers, such as CRP and VCAM-1, and higher content of haemoglobin, which reflects a high thrombus burden. Protein nitration is a usual process in the living organism and $3-\mathrm{NO}_{2}-\mathrm{Tyr}$ accumulates during the aging process reflecting the basal nitroxidative stress normally produced [25]. Each of the individual major risk factors for atheromatosis (hyperglycaemia, hypercholesterolemia, smoking and hypertension) produces endothelial dysfunction and therefore facilitates nitroxidative stress [26]. Moreover, 3- $\mathrm{NO}_{2}-\mathrm{Tyr}$ have been shown to increase the expression of tissue factor, leading to a prothrombotic state and higher blood viscosity $[10,25]$. 3-NO2-Tyr, a blood determinant that has shown independent predictors of cardiovascular risks and modulation by statin therapy in a small clinical study [27] has achieved a number of milestones although not used in clinical practice. On the other hand, the fibrinogen is a soluble plasma protein that plays an important function during clot formation. An increase of nitration of fibrinogen has been detected in coronary artery disease [25]. The functional consequences this nitration produces, among other effects, modification in the molecular architecture of the protein with evident amplifying signals towards clot formation [28]. Therefore, interaction between 3-NO2-Tyr and inflammation suggest that it plays an important role in plaque instability and the subsequent formation and release of thrombus.

There were several study limitations. First, the number of patients was relatively small, as in other studies [16], therefore, our findings should be interpreted as hypothesis-generating. Second, difficulties associated with the determination of the actual amount of thrombus present in the vessel as well as difficulties with the use of the coronary angiography to determine the complete removal of the thrombus made it difficult to provide an accurate determination. Third, a contemporary assessment of plaque morphology by optical coherence tomography that can be used to assess the relationship between thrombus characterization and plaque morphology was lacking. Fourth, due to the design of this study we have not assessed the infiltration of different inflammatory cell types in the thrombi. Fifth, we have not investigated the effect of onset-of-pain-to-PCI time on the composition of STEMI thrombus. Finally, we did not analyze markers of reperfusion in our database.

In conclusion, it can be demonstrated by the present study that coronary thrombus with higher levels of $3-\mathrm{NO}_{2}$-Tyrcontent often contain more inflammatory markers which could have a direct impact on the efficacy of drugs or devices used for coronary reperfusion.

\section{Acknowledgements}

Thank you to the following: Ms. Veronica Dominguez-Gonzalez for technical assistance and to Celine of JC OnLine Business Consulting for her linguistic revision of this manuscript.

\section{Sources of Funding}

This study was supported by grants from the Spanish Society of Cardiology for Clinical Research in Cardiology 2014.

\section{Competing Interests}

The authors do not have competing interest.

\section{References}

1. DeWood MA, Spores J, Notske R, Mouser LT, Burroughs R, Golden MS, Lang HT. Prevalence of total coronary occlusion during the early hours of transmural myocardial infarction. N Engl J Med 1980; 303: 897-902.

2. Silvain $J$, Collet JP, Nagaswami C, Beygui $F$, Edmondson KE, Bellemain-Appaix A, Cayla G, Pena A, Brugier D, Barthelemy O, Montalescot G, Weisel JW. Composition of coronary thrombus in acute myocardial infarction. J Am Coll Cardiol 2011; 57: 1359-1367.

3. Ramaiola I, Padró T, Peña E, Juan-Babot O, Cubedo J, Martin-Yuste V, Sabate $\mathrm{M}$, Badimon L. Changes in thrombus composition and profilin-1 release in acute myocardial infarction. Eur Heart J 2015; 36: 965-975.

4. Suades R, Padró T, Vilahur G, Martin-Yuste V, Sabaté M, Sans-Roselló J, Sionis A, Badimon L. Growing thrombi release increased levels of CD235a(+) microparticles and decreased levels of activated platelet-derived microparticles. Validation in ST-elevation myocardial infarction patients. J Thromb Haemost $\quad$ 2015; 13: 1776-1786.

5. Fuentes E, Badimon L, Caballero J, Padró T, Vilahur G, Alarcón M, Pérez P, Palomo I. Protective mechanisms of adenosine 5'-monophosphate in platelet activation and thrombus formation. Thromb Haemost 2014; 111: 491-507.

6. Kumbhani DJ, Bavry AA, Desai MY, Bangalore S, Byrne RA, Jneid H, Bhatt DL. Aspiration thrombectomy in patients undergoing primary angioplasty: totality of data to 2013. Catheter Cardiovasc Interv. 2014;84:973-977.

7. Dominguez AC, Bittl JA, El-Hayek G, Contreras E, Tamis-Holland JE. Meta-analysis of randomized controlled trials comparing percutaneous coronary intervention with aspiration thrombectomy Vs. Conventional percutaneous coronary intervention during ST-segment elevation myocardial infarction. Catheter Cardiovasc Interv. 2015 Dec 23. doi: 10.1002/ccd.26352. [Epub ahead of print].

8. Sadowski M, Zabczyk M, Undas A. Coronary thrombus composition: links with inflammation, platelet and endothelial markers. Atherosclerosis 2014; 237: 555-561.

9. Yunoki K, Naruko T, Komatsu R, Ehara S, Shirai N, Sugioka K, Nakagawa M, Kitabayashi C, Ikura Y, Itoh A, Kusano K, Ohe T, Haze K, Becker AE, Ueda M. Enhanced expression of haemoglobin scavenger receptor in accumulated macrophages of culprit lesions in acute coronary syndromes. Eur Heart J 2009; 30: 1844-1852.

10. Yedgar S, Hovav T, Barshtein G. Red blood cell intercellular interactions in oxidative stress states. Clin Hemorheol Microcirc 1999; 21: 189-193.

11. Yunoki $K$, Naruko $T$, Sugioka $K$,Inaba M, Iwasa $Y$, Komatsu R, Itoh A, Haze $K$ Inoue $\mathrm{T}$, Yoshiyama M, Becker AE, Ueda M. Erythrocyte-rich thrombus aspirated from patients with ST-elevation myocardial infarction: association with oxidative stress and its impact on myocardial reperfusion. Eur Heart J 2013; 33: 1480-1490.

12. Ignarro LJ, Napoli C, Loscalzo J. Nitric oxide donors and cardiovascular agents modulating the bioactivity of nitric oxide: an overview. Circ Res 2002; 90: $21-28$

13. Kooy NW, Lewis SJ, Royall JA, Ye YZ, Kelly DR, Beckman JS. Extensive tyrosine nitration in human myocardial inflammation: evidence for the presence of peroxynitrite. Crit Care Med 1997; 25: 812-819.

14. Dominguez-Rodriguez A, Avanzas P, Consuegra-Sanchez L, Sanchez-Grande A, Abreu-Gonzalez P, Conesa-Zamora P. Inflammatory markers in blood and thrombus aspirated from patients with acute myocardial infarction with ST-segment elevation: ARTERIA trial study design and rationale. Biomarkers 2013; 18: 369-372.

15. Van de Werf F, Bax J, Betriu A, Blomstrom-Lundqvist C, Crea F, Falk V, Filippatos G, Fox K, Huber K, Kastrati A, Rosengren A, Steg PG, Tubaro M, Verheugt F, Weidinger F, Weis M; ESC Committee for Practice Guidelines (CPG). Management of acute myocardial infarction in patients presenting with 
persistent ST-segment elevation: the Task Force on the Management of ST-Segment Elevation Acute Myocardial Infarction of the European Society of Cardiology. Eur Heart J 2008; 29: 2909-2945.

16. Yunoki K, Naruko T, Sugioka K, Inaba M, Itoh A, Haze K, Yoshiyama M, Ueda M. Thrombus aspiration therapy and coronary thrombus components in patients with acute ST-elevation myocardial infarction. J Atheroscler Thromb 2013; 20:524-537.

17. Li R, Ren M, Luo M, Chen N, Zhang Z, Luo B, Wu J. Monomeric C-reactive protein alters fibrin clot properties on endothelial cells. Thromb Res 2012; 129: e251-e256.

18. Takano M, Inami S, Ishibashi F, Okamatsu K, Seimiya K, Ohba T, Sakai S, Mizuno K. Angioscopic follow-up study of coronary ruptured plaques in nonculprit lesions. J Am Coll Cardiol 2005; 45: 652-658.

19. Matsuda S, Yamashita A, Sato Y, Kitajima S, Koike T, Sugita C, Moriguchi-Goto S, Hatakeyama K, Takahashi M, Koshimoto C, Matsuura Y, Iwakiri T, Chen YE, Fan J, Asada Y. Human C-reactive protein enhances thrombus formation after neointimal balloon injury in transgenic rabbits. J Thromb Haemost 2011; 9: 201-208.

20. Youssef AA, Chang LT, Sheu JJ, Lee FY, Chua S, Yeh KH, Yang CH, Wu CJ, Yip HK. Association between circulating level of CD40 ligand and angiographic morphologic features indicating high-burden thrombus formation in patients with acute myocardial infarction undergoing primary coronary intervention. Circ J 2007; 71:1857-1861.

21. Henn V, Slupsky JR, Grafe M, Anagnostopoulos L, Forster R, Muller BerghausG, Kroczek RA. CD40 ligand on activated platelets triggers an inflammatory reaction of endothelial cells. Nature 1998; 391: 591-594.

22. Dominguez-Rodriguez A, Abreu-Gonzalez P, Avanzas P, Bosa-Ojeda F, Samimi-Fard S, Marrero-Rodriguez F, Kaski JC. Intracoronary versus intravenous abciximab administration in patients with ST-elevation myocardial infarction undergoing thrombusaspiration during primary percutaneous coronary intervention--effects on soluble CD40 ligand concentrations. Atherosclerosis. 2009;206:523-527.

23. Piccolo R, Eitel I, Iversen AZ, Gu YL, Dominguez-Rodriguez A, de Smet BJ, Mahmoud KD, Abreu-Gonzalez P, Thiele H, Piscione F. Intracoronary versusintravenous bolus abciximab administration in patients undergoing primary percutaneous coronary intervention with acute ST-elevation myocardial infarction:a pooled analysis of individual patient data from five randomised controlledtrials. EuroIntervention. 2014;9:1110-1120.

24. Piccolo R, Eitel I, Galasso G, Iversen AZ, Gu YL, Dominguez-Rodriguez A, de Smet BJ, Mahmoud KD, Abreu-Gonzalez P, Thiele H, Piscione F. Intracoronary abciximab in diabetic patients with ST-segment elevation myocardial infarction undergoing primary percutaneous coronary intervention. Vascul Pharmacol. 2015;73:32-37.

25. Peluffo G, Radi R. Biochemistry of protein tyrosine nitration in cardiovascular pathology. Cardiovasc Res 2007; 75: 291-302.

26. Widlansky ME, Gokce N, Keaney JF Jr, Vita JA. The clinical implications of endothelial dysfunction. J Am Coll Cardiol 2003; 42:1149-1160.

27. Shishehbor MH, Aviles RJ, Brennan ML, Fu X, Goormastic M, Pearce GL Gokce N, Keaney JF Jr, Penn MS, Sprecher DL, Vita JA, Hazen SL. Association of nitrotyrosine levels with cardiovascular disease and modulation by statin therapy. JAMA 2003; 289: 1675-1680

28. Kotur-Stevuljevic J, Memon L, Stefanovic A, Spasic S, Spasojevic-Kalimanovska V, Bogavac-Stanojevic N, Kalimanovska-Ostric D, Jelić-Ivanovic Z, Zunic G. Correlation of oxidative stress parameters and inflammatory markers in coronary artery disease patients. Clin Biochem 2007; 40: 181-187. 